\title{
ESTRATEGIAS DE LAS FAMILIAS CAMPESINAS EN PUEBLO NUEVO, MUNICIPIO DE ACAMBAY, ESTADO DE MÉXICO
}

\author{
STRATEGIES OF PEASANT FAMILIES IN PUEBLO NUEVO, MUNICIPALITY OF \\ ACAMBAY, ESTADO DE MÉXICO
}

Edgar Magdaleno-Hernández, ${ }^{1 *}$ Mercedes A. Jiménez-Velazquez, ${ }^{1}$ Tomas Martínez-Saldaña, ${ }^{1}$ Bartolome Cruz-Galindo ${ }^{2}$

\begin{abstract}
1Desarrollo Rural. (magdaleno.edgar@colpos.mx) (mjiménez@colpos.mx) (tms@colpos.mx) ${ }^{2}$ Economía. Campus Montecillo. Colegio de Postgraduados. 56230. Montecillo, Estado de México. (bcruzg@colpos.mx)
\end{abstract}

\section{RESUMEN}

El estudio muestra los mecanismos que realizan las familias campesinas de la comunidad de Pueblo Nuevo para satisfacer sus necesidades básicas de alimentación y asegurar su reproducción. Las familias trabajan en la búsqueda del sustento alimenticio y complementan su ingreso con otras actividades no agrícolas; en su dinámica campesina se analiza la estrategia de producción dirigida al auto-abasto alimentario y al mercado con el propósito de conocer su importancia. Se utiliza metodología mixta: método cualitativo y cuantitativo, aplicando una encuesta a 35 jefes de familia. La práctica de una agricultura tradicional que fusiona el cultivo de maíz (criollo); manejo de milpa en la pre-siembra, agregando material orgánico; y, en traspatio, sistema de crianza de ganado menor. La estrategia más representativa de la familia campesina es el auto-abasto, ya que complementa su sustento familiar para garantizar la reproducción campesina; se ocupan en trabajos temporales en la misma región que genera un ingreso extra. Por otra parte, para algunas familias es significativo el recurso proveniente de algún familiar que emigra hacia otro lugar.

Palabras clave: agricultura tradicional, cultivo básico, productor.

\section{INTRODUCCIÓN}

L a investigación seorealizó en la comunidad de Pueblo Nuevo, Municipio de Acambay, Estado de México. Tiene como objetivo caracterizar a las familias campesinas con base en el autoabasto alimentario y la ocupación de mano de obra. El trabajo familiar y su funcionamiento está organizado para la producción, con la intención de satisfacer el

* Autor responsable * Author for correspondence.

Recibido: diciembre, 2013. Aprobado: abril, 2014.

Publicado como ARTÍCULO en ASyD 11: 167-179. 2014.

\section{Abstract}

The study shows the mechanisms that peasant families use in the community of Pueblo Nuevo to satisfy their basic dietary needs and to guarantee their reproduction. The families work in the search for food sustenance and they complement their income with other non-agricultural activities; in their peasant dynamic, the food production strategy directed at auto-supply and the market is analyzed, with the goal of understanding its importance. A mixed methodology is used: qualitative and quantitative methods, applying a survey to 35 heads of households. Traditional agriculture is practiced, which combines maize (Creole) cultivation, managing the milpa during pre-sowing by adding organic material, and a backyard breeding system for small livestock. The most representative strategy of the peasant family is auto-supply, since it complements the family's sustenance to guarantee peasant reproduction; they are occupied with temporary jobs in the same region, generating extra income. On the other hand, for some families the resources received from a family member who migrates somewhere different are also significant.

Key words: traditional agriculture, basic crop, producer.

\section{INTRODUCCIÓN}

The research was performed in the community of Pueblo Nuevo, municipality of Acambay, Estado de México. It has the objective of characterizing peasant families based on their food auto-supply and occupation of the workforce. Family labor and its functioning is organized for production, with the intention of satisfying the annual budget for family consumption (auto-supply), structured by an extension of land, means of production, plants and animals, where members transfer energy and 
presupuesto anual del consumo familiar (autoabasto), estructurada por una extensión de tierra, medios de producción, plantas y animales, donde sus integrantes transfieren energía y saberes al trabajo agrícola (tierra, plantas y animales) para obtener sus alimentos con estrategias campesinas que persiguen mejorar en cada ciclo agrícola (Altieri y Nicholls, 2013; Martínez, 1987).

Se plantearon como hipótesis: 1) La disminución de mano de obra familiar y la modificación en las necesidades de autoabasto han generado cambios en el patrón de cultivos, la polarización social y la migración; 2) El acceso al apoyo agrícola es inequitativo ya que solo beneficia a campesinos con mayores ingresos, quienes pueden cultivar diversos productos de mayor valor en el mercado.

El estudio se enfoca a conceptualizar a los campesinos a través de algunos teóricos clásicos; entre ellos están Chayanov (1974), Wolf (1975) y Martínez (1985). Los autores coinciden en que los campesinos se identifican por tener una economía familiar; son pequeńos productores con tierra, laboran con ayuda de equipo simple y el trabajo de su familia produce para su propio consumo. También se caracterizan por ser labradores y ganaderos; se identifican como un grupo, el cual comparte aspectos socioeconómicos y culturales. Principalmente, la unidad campesina está dedicada a cultivar para el sustento alimenticio.

\section{LA FAMILIA CAMPESINAL}

La familia campesina, se define como una insttución y grupo social. El sustento familiar, basado en una relación a través del matrimonio, parentesco y la adopción, que incluye a otra persona; los miembros conviven y cooperan en el marco de una división de actividades y tareas, socialmente determinada y reconocida (Galeski,(1997).

La base de la especificidad de la familia campesina es el cultivo de la tierra, fuente de sus principales características que se integran de varios aspectos:

- Poseen sus propios medios de producción. La unidad doméstica campesina es autónoma, referente a la satisfacción de las necesidades de sus miembros.

- El ámbito de sus funciones es amplio; se desempeñan de una manera permanente porque el individuo está arraigado y subordinado a la familia que es más solidaria. knowledge to agricultural work (land, plants and animals) to obtain their food with peasant strategies that they aim to improve in each agricultural cycle (Altieri and Nicholls, 2013; Martínez, 1987).

The following hypotheses were set out: 1) The decrease of family labor and the modification in auto-supply needs have generated changes in the crop pattern, social polarization and migration; 2) Access to agricultural support is unequal, since it only benefits peasants of higher income, who could cultivate various products of higher value in the market.

The study was focused on conceptualizing peasants through some classical theories; among them, those by Chayanov (1974), Wolf (1975) and Martínez (1985). The authors agree in that peasants are identified by having a familiar economy; they are small-scale producers with land, who cultivate with the help of simple equipment, and labor by the family produces for their own consumption. They are also characterized by being farmers and livestock producers; they are identified as a group which shares socioeconomic and cultural aspects. Mainly, the peasant unit is devoted to cultivating for dietary sustenance.

\section{The PEASANT FAMILY}

The peasant family is defined as an institution and social group. Family sustenance, based on the relationship through marriage, kinship and adoption, which includes another person; members coexist and cooperate within the framework of a division of activities and tasks that is socially determined and recognized (Galeski, 1997).

The basis of the specificity of the peasant family is land cultivation, source of its principal characteristics which are integrated from several aspects:

- They have their own means of production. The peasant domestic unit is autonomous, referring to the satisfaction of needs of its members.

- The scope of their functions is broad; they are performed permanently because the individual is rooted and subordinate to the family that is more supportive.

- The peasant family resorts to community support to carry out its functions. 
- La familia campesina acude al apoyo de la comnidad para la realización de sus funciones.

En la comunidad de estudio la familia desempeña la primera forma de organización social por las diferentes actividades que cada integrante de la misma realiza, no solo para su funcionamiento endógeno sino por la relevancia que tiene su dinamismo en el ámbito comunitario. Por otra parte, la familia campesina trata de satisfacer sus necesidades (mínimo calórico, autoabasto, enseres agrícolas y fiestas patronales) antes que obtener ganancias. Esto es, el campesino aparece como unidad de producción y consumo, no como individuo o como sector agropecuario desligado de una familia.

La unidad doméstica campesina produce tanto para su autoabasto como para el mercado; además, realiza actividades extra finca, incluyendo la migración. El tamańo y composición de la familia juega un papel trascendente porque la mano de obra es el sustento de la economía campesina. Por ello, los campesinos tratan de satisfacer necesidades de la familia, más que obtener ganancia. (Chayanov,(1974).

Eric Wolf (1975) describe a la familia como el primer escalón de la estructura social y hace énfasis en las unidades domésticas campesinas de México. En ellas era evidente un contexto de comunidad y una serie de toma de decisiones económicas, sociales y políticas. El autor advierte que entender las relaciones que existen al interior y exterior de la comunidad dependen del tipo de familia, sea nuclear o extensa. Las primeras están conformadas por cónyuges y sus hijos; las extensas se agrupan de varias familias nucleares que son más complejas: abuelos, padres, hijos, tíos solteros, viudas, bisnietos, familiares no consanguíneos, etcétera.

El tipo de familia campesina deriva de la capacidad para alimentar a todos sus integrantes; sus técnicas de producción, diversificación de actividades de manutención y el contexto cultural. Su principal desafío es resguardar la alimentación y, después, ayudar a mantener la organización social y orden en su comunidad (Wolf, 1975).

El trabajo familiar es la base de la actividad campesina y, dependiendo de sus necesidades, se emplean en otra actividad. De acuerdo con el grado en que incremente su nivel económico, su posición o característica campesina puede modificarse, de tal manera que pasa a otro grupo socioeconómico (Figura 1).
In the community of study, the family performs the first form of social organization through the different activities that each member carries out, not only for their endogenous functioning but also from the importance of its dynamism in the community scope. On the other hand, the peasant family attempts to satisfy its needs (caloric minimum, auto-supply, agricultural essentials and patron saint festivities) rather than obtaining earnings. That is, the peasant appears as a production and consumption unit, not as an individual or as agricultural/livestock sector separate from a family.

The peasant domestic unit produces both for its auto-supply and for the market; in addition, it performs activities outside the farm, including migration. The size and composition of the family plays an important role because the workforce is the foundation of the peasant economy. Therefore, peasants try to satisfy the family needs, rather than obtaining a profit (Chayanov, 1974).

Eric Wolf (1975) describes the family as the first step in the social structure and emphasizes peasant domestic units in México. In these, a context of community was evident as well as a series of economic, social and political decisions made. The author warns that understanding the relationships that exist inside and outside the community depends on the type of family, whether nuclear or extensive. The first are made up of spouses and their children; extensive ones are grouped from several nuclear families that are more complex: grandparents, parents, children, single uncles, widows, great-grandchildren, family members who are not blood-related, etc.

The type of peasant family derives from the ability to feed all its members, their production techniques, the diversification of support activities, and the cultural context. Their main challenge is to protect the diet and, then, to help maintain the social organization and order in their community (Wolf, 1975).

Family labor is the foundation of the peasant activity and, depending on their needs they are employed in other activities. According to the degree to which their economic level improves, their peasant position or characteristic can be modified, so that they move to a different socioeconomic group (Figure 1).

In social terms, peasantry is a collectivity on which the multi-active family economy is based; those who 


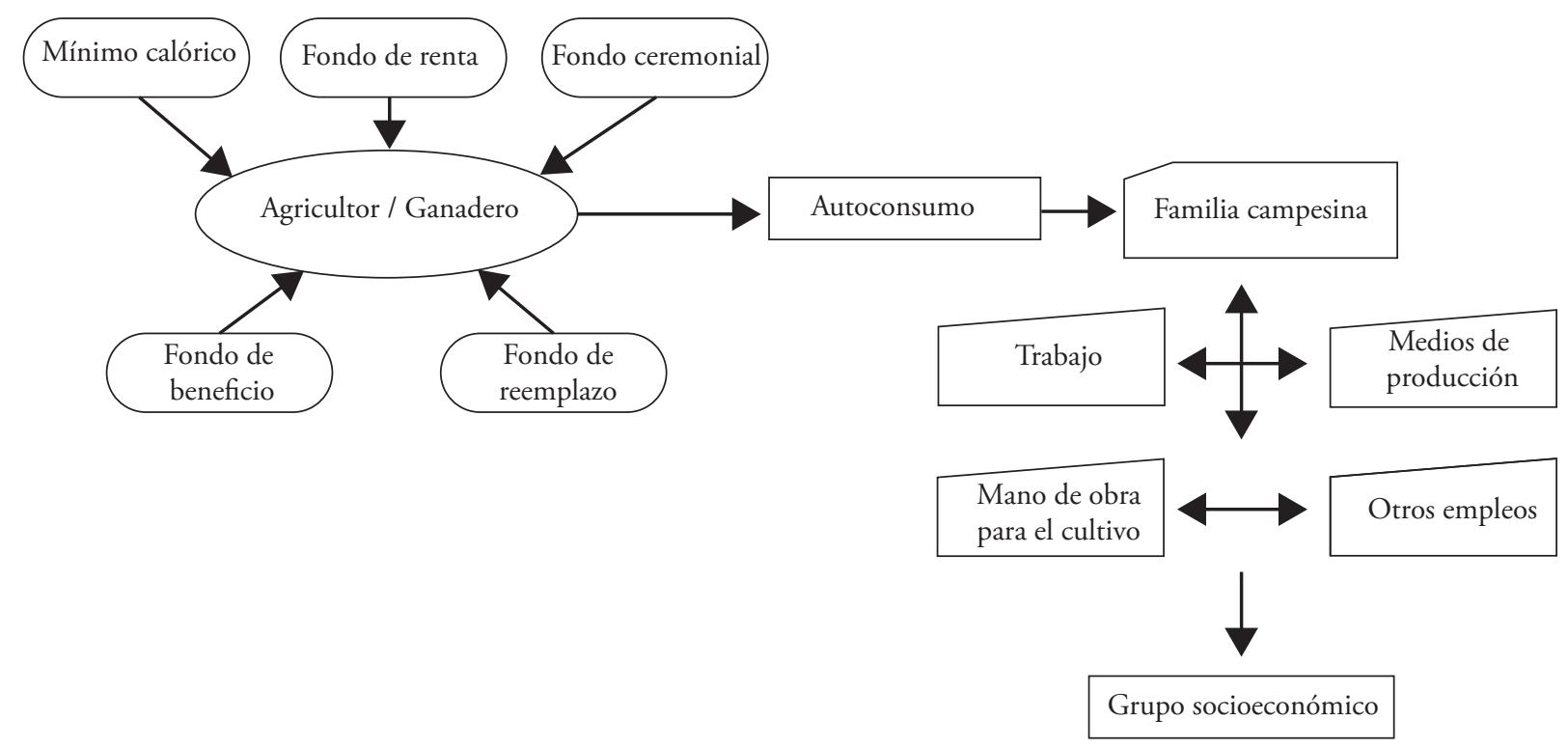

Figura 1. Trabajo familiar campesino.

Figure 1. Peasant family labor.

En términos sociales el campesinado es una colectividad en cuya base está en la economía familiar multi-activa; también forman parte quienes teniendo funciones no agrícolas participan de la vida comunitaria y comparten su destino (Bartra, 2010).

En la actualidad la sociedad rural es más compleja, resultado de varios factores ajenos a ella, forzando a las familias a generar estrategias para continuar con sus tradiciones, así como el abandono de otras para mantener un orden social. Entre los principales factores externos que condicionan a las familias campesinas a la reestructuración está la falta de atención a las necesidades del campo mexicano en las últimas cuatro décadas del siglo XX, mismas que se agudizaron en los últimos veinte años, llevando al crecimiento de la migración interna como una estrategia más de sobrevivenci. (Aparicio y Meseguer, 2010).

Esta descomposición generada por la salida de miembros de la familia impacta las actividades de cada integrante. Es relevante recordar que los diferentes momentos migratorios, tanto internos como externos, reestructuraron tanto a las familias nucleares como a las extensas. El éxodo migratorio es complejo, multifactorial y riesgoso por situaciones socioeconómicas, pertenencia a su lugar de origen e identidad. Por ello, en diversas situaciones la forma más efectiva de organización familiar es la extens (Arana, Rodríguez y Carrasco, 2009). participate in community life and share their destiny, even having non-agricultural functions, are also part of it (Bartra, 2010).

Currently the rural society is more complex, resulting from several factors foreign to it, which force families to generate strategies to continue with their traditions, as well as others to abandon them to maintain a social order. Among the primary external factors that condition peasant families to this restructuring is the lack of attention to the needs of the Mexican countryside during the last four decades of the $20^{\text {th }}$ Century, which have become more acute during the past 20 years, leading to the increase in domestic migration as another strategy for survival (Aparicio and Meseguer, 2010).

This decomposition generated by the exit of family members has an impact on the activities of each member. It is important to remember that the different migratory moments, both internal and external, have restructured nuclear families as much as extensive ones. The migratory exodus is complex, multifactorial and risky as a result of socioeconomic situations, belonging to their place of origin and identity. Therefore, in various situations the most effective form of family organization is the extensive one (Arana, Rodríguez and Carrasco, 2009).

In Pueblo Nuevo, producers practice a traditional agriculture that involves three environments: socioeconomic, social and cultural. They work in 
En Pueblo Nuevo los productores practican una agricultura tradicional que involucra tres entornos: socioeconómico, social y cultural. Trabajan en familia, donde la mano de obra es el sustento de la economía campesina. Las familias realizan diversas actividades complementarias tanto dentro como fuera de la parcela con el propósito de subsanar carencias y riesgos del trabajo agrícola; la labor complementaria más representativa es la asalariada.

Las plantas silvestres, como los quelites, y los hongos se recolectan para la alimentación familiar; nacen de manera natural en la milpa y la zona boscosa (altitud 2700 a $3800 \mathrm{~m}$ ). A través de la observación participante se rescata el conocimiento tradicional campesino en el hábitat del acopio de estas plantas, su clasificación nativa, sus usos y su consumo alimentari (Jiménez, 2010).

Por otra parte, en Pueblo Nuevo está la milpa que es el lugar de cultivo, un campo sembrado de maíz con diversas plantas y granos donde se aprovecha la mayoría de sus partes. Tradicionalmente en la milpa se privilegió un tipo de cultivo (orgánico): el rastrojo, que se usa como abono natura (Buenrostro, 2008).

La agricultura tradicional (Figura 2) en la comunidad fusiona el sistema de cultivo maíz blanco (criollo) y la crianza de ganado menor (borregos, vacas, porcinos, aves). De esta manera, la fertilización del terreno del cultivo es el estiércol del ganado menor, aprovechando el subproducto (estiércol) para emplearlo como fertilizante. Además, el subproducto zacate molido, los rastrojos o esquilmos tienen un valor equivalente al del grano de maíz, ya que en la época de estiaje (noviembre-abril) se convierte en la única fuente de alimentación del ganado.

El principal cultivo es el maíz blanco (Zea mays L.) y, en menor medida, frijol (Phaseolus vulgaris, Lin) y calabaza (Cucúrbita moschata, Potret), que son productos fundamentales para la seguridad alimentaria de la familia campesina. Un kilogramo de maíz, sorgo (Sorghum vulgare), arroz (Oryza sativa) o trigo (Triticum aestivum) contiene 3400 calorías. Esto significa que una persona requiere $236 \mathrm{~kg}$ de maíz al año (Grigg, 1973). Por tal razón, una familia típica campesina en la zona de estudio (5 a 8 miembros) necesita de 1180 a $1888 \mathrm{~kg}$ de grano al ańo.

En este contexto se rescata la agricultura tradicional, que implica asociación de cultivos (no solo monocultivo), mejoramiento de recursos, ahorro de the family, where labor is the support of the peasant economy. Families carry out various complementary activities both within and outside the farm, with the purpose of compensating for shortages and risks in agricultural work; the most representative complementary work is as salaried employees.

Wild plants, such as quelites, and fungi are collected for the family diet; they grow naturally in the milpa and the forest area (altitude of 2700 to 3800 masl). Through participant observation, the peasant traditional knowledge about the environment where these plants are harvested is rescued, as well as their native classification, their uses and their dietary consumption (Jiménez, 2010).

On the other hand, in Pueblo Nuevo there is the milpa, which is the cultivation area, a field sown with maize and various plants and grains where most of its parts are used. Traditionally, in the milpa, a type of cultivation (organic) was privileged: using stubble (rastrojo) as a natural fertilizer (Buenrostro, 2008).

Traditional agriculture (Figure 2) in the community fuses the cultivation system for white (Creole) maize and the breeding of small livestock (sheep, cows, pigs, and poultry). Thus, fertilization of the cultivation plot is done with dung from the small livestock, taking advantage of the sub-product to be used as fertilizer. Also, the sub-product made up of ground fodder, stubble or residues, has a value equivalent to the maize grain, since during the time of low water availability (November-April), this becomes the sole source of food for the livestock.

The main crop is white maize (Zea mays L.) and, to a lesser degree, bean (Phaseolus vulgaris, Lin) and squash (Cucúrbita moschata, Potret), which are fundamental products for food security of the peasant family. A kilogram of maize, sorghum (Sorghum vulgare), rice (Oryza sativa) or wheat (Triticum aestivum) contains 3400 calories. This means that a person requires $236 \mathrm{~kg}$ of maize per year (Grigg, 1973). Therefore, a typical peasant family in the study area (5 to 8 members) needs 1180 to $1888 \mathrm{~kg}$ of grain per year.

Within this context, traditional agriculture is rescued, which entails crop association (not only single crops), resource improvement, input savings (organic fertilizers and use of fodder), soil protection, risk distribution (association of crops and livestock), water use, higher yield (diversifying products), and biodiversity by using few chemicals. 


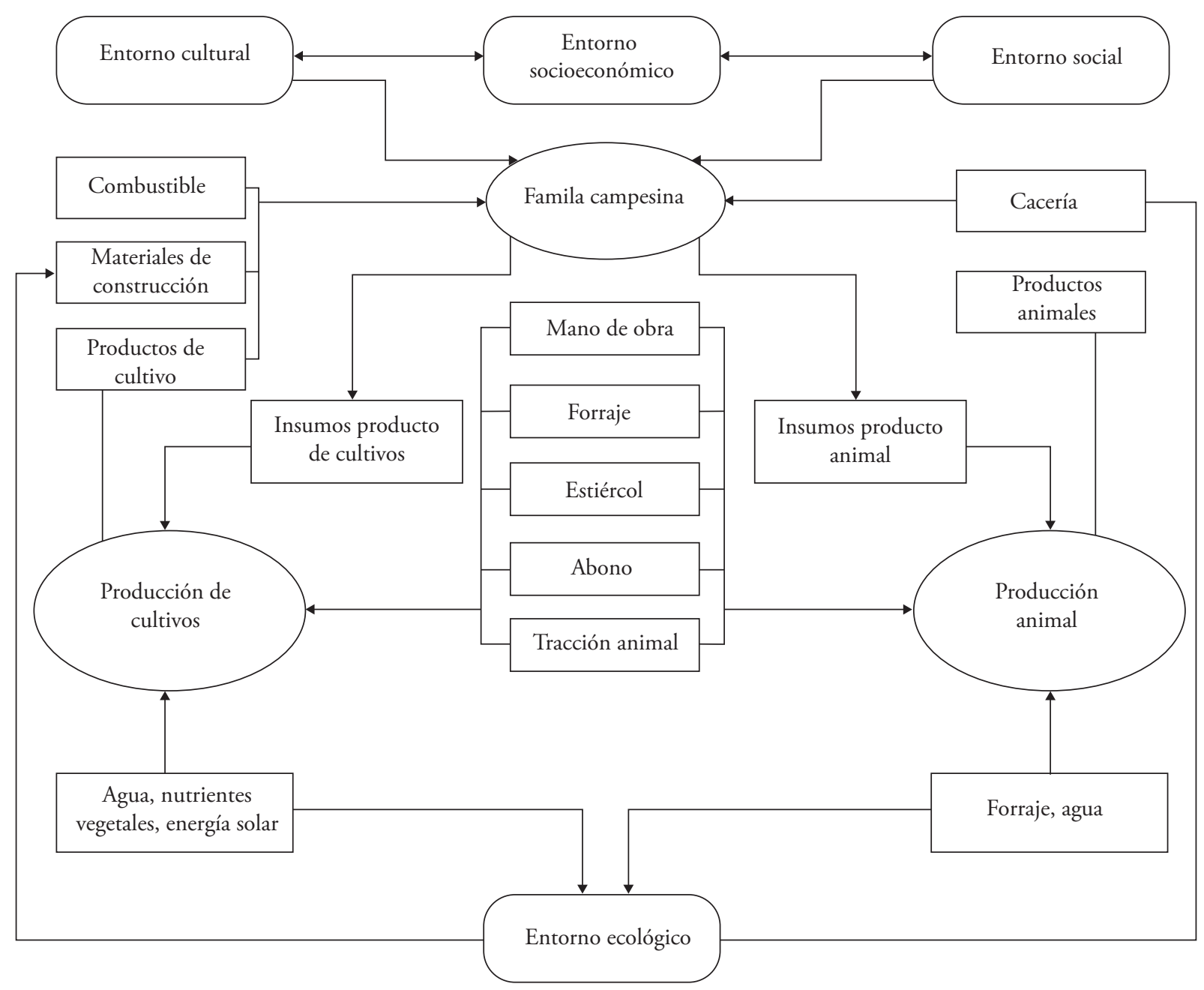

Figura 2. Agricultura Tradicional Campesina, Pueblo, Nuevo Acambay.

Figure 2. Traditional peasant agriculture, Pueblo Nuevo, Acambay.

insumos (abonos orgánicos y aprovechamiento de zacate), protección del suelo, distribución de riesgos (asociación de cultivos y ganado), aprovechamiento de agua, mayor rendimiento (diversificar productos) y biodiversidad al usar pocos químicos.

Las familias financian sus actividades productivas con ahorros familiares y parte de esos recursos los obtienen al dedicarse a otros trabajos temporales, o bien, de familiares que emigran tanto a la Ciudad de México como a otros estados; otros parten hacia EE. UU.

\section{Metodología}

El municipio de Acambay se encuentra en la parte norte del Estado de México. Dentro del municipio existen seis valles; Pueblo Nuevo se encuentra en el llamado Valle de los Espejos, ubicado a $6 \mathrm{~km}$
Families finance their productive activities with their savings and part of these resources are obtained from employing themselves in other temporary work, or else from family members who migrate both to Mexico City and other states, or those who depart towards the USA.

\section{Methodology}

The municipality of Acambay is located on the northern part of Estado de México. Within the municipality, there are six valleys; Pueblo Nuevo is found in Valle de los Espejos, $6 \mathrm{~km}$ away from the municipal township of Acamba (INEGI, 2010) (Figure 3).

Obtaining information about agricultural work and auto-supply of peasant families was done through a mixed methodology. For this purpose, 
de distancia de la Cabecera Municipal de Acamba (INEGI, 2010) (Figura 3).

La obtención de información del trabajo agrícola y auto-abasto de familias campesina, se aborda a través de metodología mixta. Para ello se realiza una investigación con el método cualitativo y cuantitativo. Se diseña un cuestionario, utilizando variables de la investigación (Hernández et al., 2005); se aplicaron técnicas de investigación social: observación participante, taller participativ (GeilfuF, 2002) y aplicación de un cuestionario de 50 preguntas a 35 jefes de familias campesinas de la comunidad.

Según Wolf (1975), una familia campesins representativa de la zona de estudio realiza actividades agrícolas y no agrícolas. En el trabajo de campo fue fundamental contar con la confianza de los jefes de familia entrevistados para obtener la información y lograr los objetivos de la investigación.

El levantamiento de información en campo se lleva a cabo (junio y julio 2012), considerando las actividades cotidianas del productor y su familia. La aplicación de encuestas generó datos; por ello, se deduce que se logró el ambiente de confianza necesario. La fase exploratoria y las entrevistas con informantes claves permitieron concluir que las familias campesinas presentan características homogéneas en términos de los cultivos que producen, tamaño de parcela y tierras research with qualitative and quantitative methods was performed. A questionnaire was designed, using research variables (Hernández et al., 2005); social research techniques were applied: participant observation, participative workshop (GeilfuF, 2002), and a questionnaire of 50 questions was applied to 35 peasant heads of households from the community.

According to Wolf (1975), a representative peasant family from the study area performs agricultural and non-agricultural activities. During the field work, it was essential to have the trust of the heads of households interviewed, in order to obtain information and achieve the objectives of the study.

Gathering information on the field took place (June and July, 2012), taking into account the daily activities of the producer and his/her family. Application of the surveys generated data; therefore, it was deduced that the necessary environment of trust was achieved. The exploratory phase and the interviews with key informants allowed concluding that peasant families present homogeneous characteristics in terms of the crops they produce, the size of the plot, and the rainfed lands. As a result of these causes, the decision to use a simple randomized sample was made (Hernández et al., 2005). It is considered that the sample corresponds to $5 \%$ of the population, and that it is enough because of the similar characteristics of peasant families.

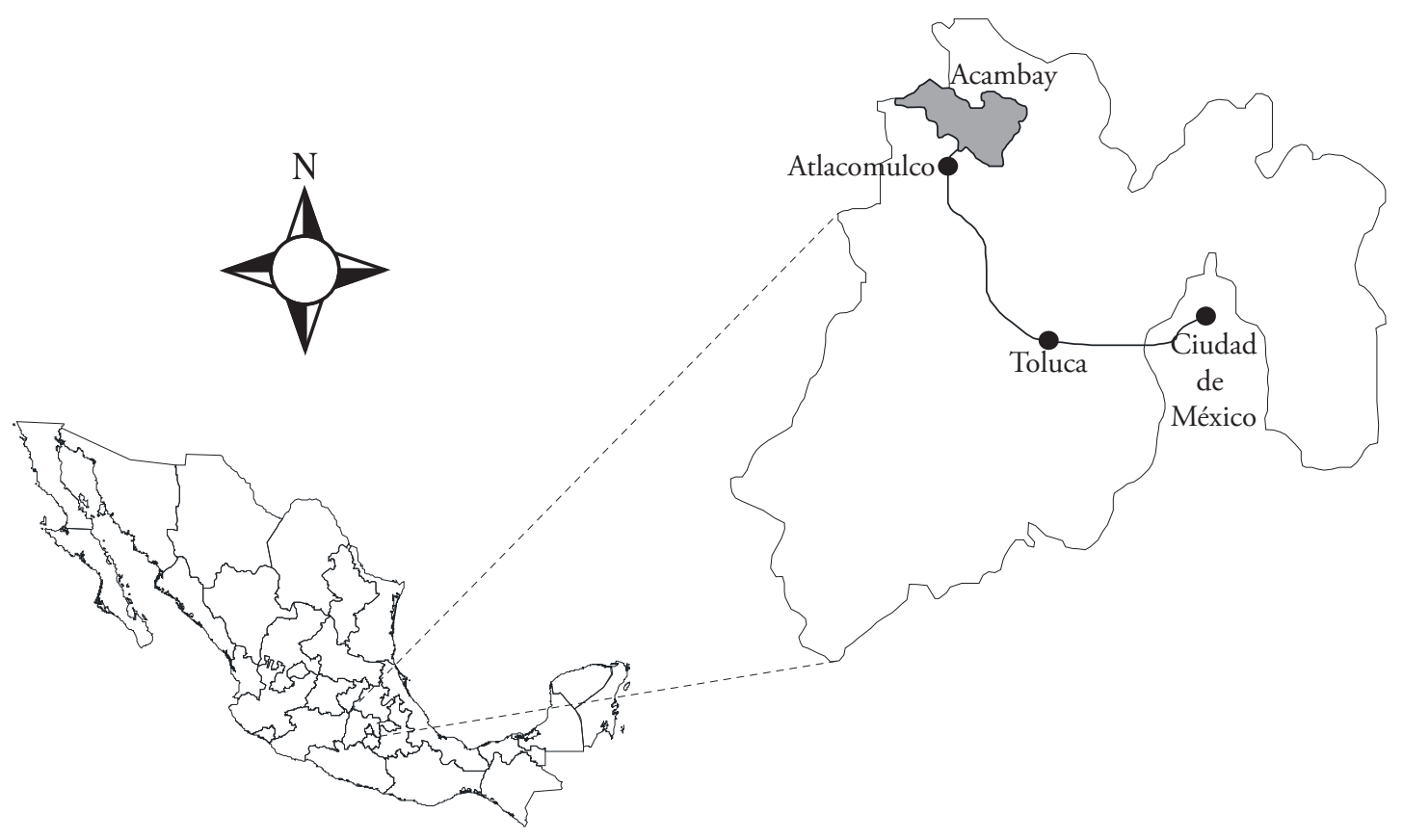

Figura 3. Macro localización del Municipio de Acambay.

Figure 3. Macro localization of the municipality of Acambay. 
de temporal. Por esas causas se toma la decisión de practicar un muestreo simple aleatorio (Hernández, et al., 2005). Se considera que la muestra corresponde a $5 \%$ de la población y es suficiente po las características similares de las familias campesinas.

Los datos obtenidos se analizan, siguiendo la estadística descriptiva (Infante, 2005), utilizando el programa Excel en sus diversas aplicaciones (gráficas, promedios, frecuencias) También, con la información cualitativa se elabora una tipología de productores.

\section{Resultados y Discusión}

Los resultados corresponden a los objetivos de la investigación y a los datos relevantes que arroja la misma. La edad promedio de los campesino jefes de familia encuestados es de 44 ańos; el menor tiene 21 y el mayor, 74 años. La media reporta edades entre 31 y 50 años de edad; la mayoría de los productores jefes de familia son campesinos en edad madura. En relación con la distribución de productores por género, la encuesta arrojó que $73 \%$ son hombres y $27 \%$ mujeres.

El promedio de hijos por familia es un aspecto relevante. De acuerdo con las personas entrevistadas, a mayor número de hijos(as) se dispone con mano de obra para realizar actividades agrícolas. Así, el trabajo será más sencillo porque más personas podrían ayudar con su fuerza de trabajo en diversas labores de campo. En este sentido, la información obtenida alcanza $69 \%$ con más de cuatro hijos y $31 \%$ menor a esos integrantes.

En relación con el nivel de estudios reportado por los entrevistados, $34 \%$ tiene primaria no terminada; $27 \%$, primaria terminada; $33 \%$, secundaria; $6 \%$, nivel bachillerato o universitario; $13 \%$ no sabe leer y escribir; y $87 \%$ leen y escriben, es decir, tiene una escolaridad básica. Al contrastar datos censales sobre el grado promedio escolar de la población mayor de 15 años, se tiene que a nivel municipal es de $6.1 \%$, si se contrasta a nivel estatal $(9.1 \%)$ y nacional $(8.6 \%)$ Se puede decir que la escolaridad de los campesinos e básic (INEGI, 2010).

Conforme a la encuesta, datos obtenidos reportan en cada unidad de producción que $63 \%$ de familias campesinas tiene aves de traspatio, 24\% cuenta con borregos (Ovis aries) y $13 \%$ posee animales de trabajo (burros, mulas). Las aves (gallinas, guajolotes, patos) se utilizan para alimentación. Es frecuente que
The data obtained are analyzed following descriptive statistics (Infante, 2005), using the Excel software in its various applications (graphs, averages, frequencies). Also, a typology of producers was made with the qualitative information.

\section{Results AND Discussion}

The results correspond to the objectives of the research and to the relevant data generated. The average age of the peasant heads of households surveyed was 44 years; the youngest is 21 and the oldest, 74. The mean reports ages between 31 and 50 years; most of the producer heads of households are peasants of mature age. With regard to the distribution of producers by gender, the survey resulted in $73 \%$ male and $27 \%$ female.

The average of children per family is an important aspect. According to the people interviewed, the higher the number of children, there is workforce available to carry out agricultural activities. Thus, the work will be simpler because more people can help with their labor in different field tasks. In this sense, the information obtained reaches $69 \%$ with more than four children and $31 \%$ with less than that number.

In terms of the level of studies reported by those interviewed, $34 \%$ have unfinished primary school; $27 \%$ have finished primary school; $33 \%$ secondary school; $6 \%$ high school or university; $13 \%$ cannot read or write; and $87 \%$ read and write, that is, have some basic schooling. When comparing the census data regarding the average school level of the population older than 15 years, it is reported that at the municipal level it is $6.1 \%$, compared to the state $(9.1 \%)$ and national $(8.6 \%)$ levels. It can be said that schooling of the peasants is basic (INEGI, 2010).

Based on the survey, the data obtained report in each production unit that $63 \%$ of the peasant families have poultry in their backyards, $24 \%$ have sheep (Ovis aries), and $13 \%$ have burden animals (donkeys, mules). The birds (hens, turkeys, ducks) are used for food. It is frequent that they are consumed in family celebrations and community festivities. The sheep are for sale when there is a family need to obtain resources; also, they are used for life cycle festivities such as weddings, baptisms, or else, the school graduation of a family member.

Producers practice rainfed agriculture, although $12 \%$ of those surveyed apply auxiliary irrigation (a 
se consuman en fiestas familiares y celebraciones de la comunidad. Los borregos son para la venta cuando hay alguna necesidad familiar para obtener recursos; también, acostumbran disponer de ellos en fiestas del ciclo de vida como bodas, bautizos, o bien, la graduación escolar de algún integrante de la familia.

Los productores practican una agricultura de temporal, aunque $12 \%$ de los encuestados aplica riego de auxilio (un solo riego por ciclo) Por tanto, los campesinos dependen de las lluvias para una mejor cosecha. De acuerdo con la información obtenida, $84 \%$ de los jefes de familia siembran y cultivan maíz y otras plantas (16\%) tales como: trigo (Triticum aestivum), cebada (Hordeum vulgare L.), frijol (Phaseolus vulgaris L.), calabaza (Curcurbita moschat, Potret), haba (Vicia faba), chícharo (Pisum sativum L.) y avena (Avena sativa).

De acuerdo con la información obtenida, referente al destino final del maíz blanco, $55 \%$ de la población entrevistada dirige su producción al autoconsumo; $39 \%$, tanto al consumo como al mercado local; y $6 \%$, a la venta con un mayorista foráneo (Figura 4). Debido a que las familias campesinas tienen condiciones homogéneas se puede concluir que, en la zona de estudio, más de $90 \%$ de los campesinos que cultivan maíz lo producen con el propósito de lograr el autoabasto familiar y vender el excedente ( 0.5 a 2 ton).

Moler zacate y maíz de mazorca pequeña también son prácticas comunes; éstos se venden como forraje a comerciantes, ganaderos del municipio o vecinos de la comunidad que tienen ganado de traspatio. Una actividad común de las familias campesinas se destina a la engorda de cerdos (Sus scrofa ssp.), los cuales se consumen en fiestas familiares y son alimentados con maíz de mazorca pequeña, tortillas remojadas con sobrantes y un poco de masa.

A través de encuestas y al analizar los problemas de los campesinos, se observa que $59 \%$ de los jefes de familia se enfrentan a diversas situaciones adversas a la agricultura (poca humedad, fertilizantes caros, pudrición de nacimiento); $28 \%$ de ellos muestran su inquietud por las consecuencias generadas por el factor climático, como son heladas y sequía; y $13 \%$ comenta que las plagas son su principal problema. Sin embargo, la principal preocupación relacionada con el clima está en función de los riesgos ocasionados por el cambio climático y la vulnerabilidad social (Oswald, 2011). single irrigation per cycle). Therefore, the peasants depend on rains for a better harvest. According to the information obtained, $84 \%$ of the heads of households sow and cultivate maize and other plants (16\%), such as: wheat (Triticum aestivum), barley (Hordeum vulgare L.), bean (Phaseolus vulgaris L.), squash (Curcurbita moschat, Potret), broad bean (Vicia faba), peas (Pisum sativum L.) and oats (Avena sativa).

Based on the information obtained, referring to the final destination of white maize, $55 \%$ of the population interviewed directs its production to auto-consumption; $39 \%$ both to consumption and to the local market; and $6 \%$ to the sale with a foreign wholesaler (Figure 4). Because peasant families have homogeneous conditions, it can be concluded that in the study area, more than $90 \%$ of the peasants who cultivate maize produce it with the purpose of achieving family auto-supply, and to sell the excess (0.5 to 2 ton).

Grinding fodder and small-cob maize is also a common practice; this is sold as fodder to traders, livestock producers from the municipality, or neighbors of the community who own backyard livestock. A common activity of peasant families is destined to pig fattening (Sus scrofa spp.), which are consumed at family celebrations and are fed with small-cob maize, tortillas dampened with leftovers, and some dough.

Through surveys and when analyzing the peasants' problems, it is observed that $59 \%$ of the

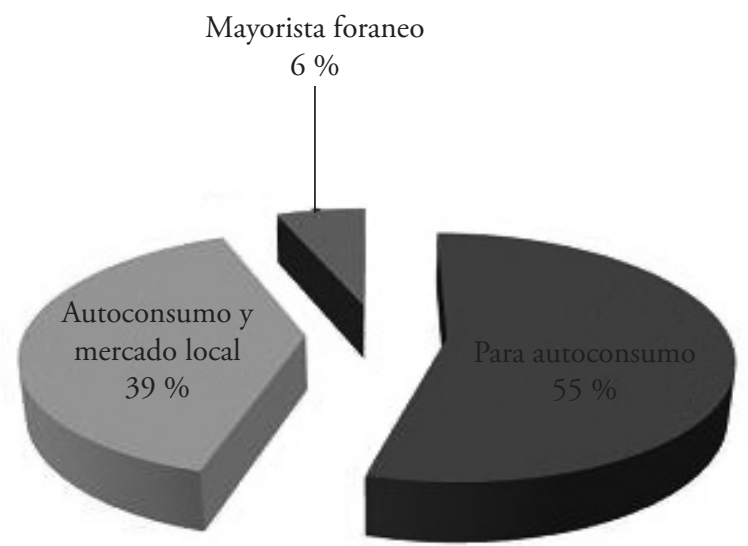

Fuente: invesstigación directa. • Source: direct research.

Figura 4. Destino de la producción.

Figure 4. Destination of the production. 
En referencia con la actividad complementaria del jefe de familia entrevistado, $23 \%$ reporta que su ingreso proviene de actividades no agrícolas, como el comercio a nivel local y regional; en sus ratos libres, $18 \%$ se dedica a elaborar artesanías (tejido de bolsas, sombreros de popote de trigo, bordado de servilletas). El porcentaje restante (59\%) realiza otras actividades para complementar su ingreso, tales como la de jornalero, o trabajos relacionados con la construcción y la ganadería a pequeña escala.

De los datos obtenidos se hace una tipología de campesinos que abarca a todos los productores de la zona. Aunque el campesino típico de la comunidad es minifundista, con una superficie que puede variar de 0.5 a 2 hectáreas, sus tierras son de temporal y para el trabajo familiar (Cuadro 1). Fundamentalmente, representa el eje de una economía local que complementa sus ingresos con otras actividades, empleos temporales y ganadería a pequeña escala subordinada a la agricultura en la que la reproducción de la unidad familia combina el auto abasto alimentario con trabajo asalariado.

El campesino que practica una agricultura empresarial (intensiva) consiste en que siembra más de un ciclo al año, utiliza semillas mejoradas, fertilizantes químicos, pesticidas químicos, uso del tractor, otros insumos (agua) y produce para el mercado (CEPAL, 1985). Dispone de una superficie de media hectárea o más, funciona como una empresa agrícola en heads of households are faced with various situations that are adverse to agriculture (scarce moisture, expensive fertilizers, birth rotting); $28 \%$ of them show their worry about the consequences generated by the climate factor, such as frost and drought; and $13 \%$ mention that plagues are their main problem. However, the primary concern related with climate is in function of the risks associated with climate change and social vulnerability (Oswald, 2011).

In terms of the complementary activity of the heads of households interviewed, $23 \%$ report that their income is from non-agricultural activities, such as commerce at the local and regional level; in their free time, $18 \%$ are devoted to elaborating handcrafts (bag weaving, hats made of wheat straw, embroidering napkins). The remaining percentage (59\%) performs other activities to complement their income, such as hiring out as day laborers, or work related to construction and small-scale livestock production.

From the data obtained, a typology of peasants is made that covers all the producers in the area. Although the typical peasant of the community is a smallholder, with a surface that can vary from 0.5 to 2 hectares, their lands are rainfed and for family labor (Table 1). Essentially, they represent the axis of local economy that complements their income with other activities, temporary jobs and small-scale livestock production subordinate to agriculture, where the reproduction

Cuadro 1. Tipología de campesinos.

Table 1. Typology of peasants.

\begin{tabular}{|c|c|c|c|c|}
\hline Tipo de ptor & $\begin{array}{c}\text { Intensivos } \\
\text { (invernadero) }\end{array}$ & Pequeños & Minifundistas & No intensivos \\
\hline Superficie & $500 \mathrm{~m}^{2}$ & 2 a 4 ha & 0.5 a 2 ha & 0.25 ha \\
\hline Tipo de propiedad & Comuneros & Comuneros y arrendados & Comunal y ejidal & Comuneros \\
\hline Tecnología & Moderna & Tradicional y moderna & Tradicional y moderna & $\begin{array}{l}\text { tradicional, insumos } \\
\text { orgánicos }\end{array}$ \\
\hline Riego o temporal & Con riego & Temporal & Temporal & Temporal \\
\hline Tipo de trabajo & Asalariado y familiar & Asalariado y familiar & Familiar & Familiar \\
\hline Mercado o autoabasto & Mercado & Autoabasto y mercado & $\begin{array}{l}\text { Autoabasto y venta de } \\
\text { excedentes }\end{array}$ & Autoabasto \\
\hline Tiempo destinado & Tiempo completo & Fines de semana & $\begin{array}{l}\text { Cuando el cultivo lo } \\
\text { requiera }\end{array}$ & Esporádico \\
\hline Tipo de cultivo & Monocultivo & Multicultivo & Multicultivo & Multicultivo \\
\hline Financi amiento & Aportaciones públicas & $\begin{array}{l}\text { Autofinanciamiento } \\
\text { familiar }\end{array}$ & $\begin{array}{l}\text { Autofinanciamiento } \\
\text { familiar }\end{array}$ & $\begin{array}{l}\text { Autofinanciamiento } \\
\text { familiar }\end{array}$ \\
\hline
\end{tabular}

Fuente: investigación de campo, otońo 2012. $•$ Source: field research, Autumn 2012. 
invernadero, aplica riego tecnificado, uso de trabajo asalariado y cuenta con financiamiento gubernamental. Estos productores exigen dedicación de tiempo completo porque se trata de un monocultivo (jitomate) dedicado al mercado. El cultivo intensivo implica que el campesino se adapte a procesos de tecnología modernos, aun sin abandonar cultivos básicos, formas de producción y vida campesina.

La tenencia de tierra del campesino promedio es ejidal con propiedad comunal. Son tierras de temporal en las que se combina el uso de tecnología tradicional y moderna; la mano de obra es familiar, la cosecha se destina al auto abasto y el excedente se vende. Asimismo, se siembra en multi-cultivo y se hace uso del autofinanciamiento familiar.

En la praxis campesina combinan el uso de tecnología tradicional y las innovaciones modernas. Es un patrón tecnológico basado en el manejo de prácticas agrícolas que son complementarias y sinérgicas, potenciando las fuerzas productivas de las familias campesinas dedicadas a la producción de maíz. (Damián et al., 2013).

En este contexto, las familias campesinas se han adaptado a diversas circunstancias: reducido tamaño de parcela, bajo nivel educativo, menor número de hijos por familia, lo cual los encamina a complementar su ingreso con otras actividades no agrícolas.

Por otra parte, el fenómeno de la migración es importante porque tiene efectos en las personas que por alguna u otra razón salen de la comunidad. El impacto de las remesas enviadas a las familias campesinas cambia hábitos de consumo local por el recurso recibido. De acuerdo con la encuesta, $82 \%$ no recibe recursos de algún familiar que se encuentra en los Estados Unidos, aunque $18 \%$ sí percibe ingresos por remesas de algún miembro de la familia; se les envían por temporadas y lo gastan principalmente en alimentación.

\section{Conclusiones}

En la comunidad de estudio el campesino promedio trabaja en familia y practica la agricultura tradicional, lo que le permite producir alimentos indispensables para su consumo básico, como maíz blanco, frijol y calabaza.

Con su tenencia de tierra y la tecnología mixta (tradicional, moderna), el jefe de familia es eje de una economía local diversificada que incluye ganadería of the family unit combines food auto-supply with salaried work.

Peasants who practice entrepreneurial agriculture (intensive) consist in cultivating more than one cycle per year, using improved seeds, chemical fertilizers, chemical pesticides, tractors, other inputs (water), and producing for the market (CEPAL, 1985). They have a surface of half a hectare or more, function as an agricultural greenhouse enterprise, apply technical irrigation, use salaried labor, and have government financing. These producers demand full-time devotion because it is a single crop (tomato) directed at the market. Intensive cultivation entails for the peasant to adapt to modern technological processes, even without abandoning basic crops, forms of production and the peasant lifestyle.

Land ownership of the average peasant is in ejidowith communal property. They are rainfed lands where the use of traditional and modern technology is combined; the workforce is familiar, the harvest is directed to autosupply, and the excess is sold. Likewise, multiple crops are sown and family auto-financing is used.

In the peasant praxis, they combine the use of traditional technology and modern innovation. It is a technological pattern based on the management of agricultural practices that are complementary and synergic, strengthening the productive forces of peasant families devoted to maize production (Damián et al., 2013).

Within this context, peasant families have adapted to diverse circumstances: smaller size of the land plot, lower educational level and fewer children per family, all of which leads them to complement their income with other non-agricultural activities.

On the other hand, the phenomenon of migration is important because it has effects on people that, for one reason or another, leave the community. The impact of remittances sent to the peasant families changes habits of local consumption because of the resource received. According to the survey, $82 \%$ do not receive resources from a family member in the United States, although $18 \%$ do get income from remittances from a member of the family; these are sent seasonally and are spent primarily in the diet.

\section{Conclusions}

In the community of study, the average peasant works with the family and practices traditional agriculture, allowing him/her to produce indispensable 
subordinada a la agricultura, elaboración artesanal en pequeña escala y comercio al menudeo, donde la reproducción de la unidad familiar combina el auto-abasto campesino, el trabajo asalariado y la multi-actividad.

La cosecha de maíz se orienta al auto-consumo y cuando hay excedente se vende al mercado local o municipal. Los subproductos de su trabajo son zacate y maíz pequeño (molonco) que se tritura con máquinas de alquiler. Se emplea para alimentar el ganado del traspatio familiar; es común vender el sobrante como forraje a nivel local o municipal.

La multi-actividad es una estrategia familiar campesina. Ocupan su mano de obra como jornaleros agrícolas, en la construcción y en otras actividades. Dependiendo de su edad, los varones combinan el trabajo familiar con sus estudios (básicos hasta nivel medio superior). Las madres de familia se hacen cargo de las labores del hogar, cuidan a los hijos y a la pareja, y apoyan en actividades agrícolas, principalmente en la cosecha.

La migración interna es otra estrategia familiar campesina. Hombres y mujeres salen de la localidad hacia EE. UU. y las remesas generadas por los empleos que desempeñan alivian parcialmente las necesidades familiares. La migración es temporal y rara vez definitiva. Se complementa con la actividad agrícola, buscando la reproducción de la unidad familiar.

Se recomienda no excluir a los campesinos tradicionales de subsidios a la agricultura, pues son quienes procuran la agro-biodiversidad del campo; además, conservan la tierra, fomentan el arraigo y mantienen la diversidad genética del maíz.

Es importante replantear el sistema invernadero para que su objetivo sea el auto-abasto familiar, económicamente al alcance de la mayoría de los campesinos, sin usar agroquímicos, para evitar un impacto negativo colateral y la captación de agua de lluvia, entre otros.

Se debe promover la conservación de ecosistemas y su biodiversidad mediante la plantación de árboles frutales adaptados a la zona en el perímetro de milpas. Esta actividad puede proporcionar más productos y mejorar el ingreso familiar campesino que permita obtener una mejor calidad de vida (alimentación) y pago por servicios ambientales.

\section{Literatura Citada}

Altieri, Miguel A., y Clara I. Nicholls. 2013. Agroecología y resiliencia al cambio climático: principios y consideraciones foods for their basic consumption, such as white maize, bean and squash.

With their land ownership and mixed technology (traditional, modern), the head of the household is the axis of a diversified local economy that includes livestock production subordinate to agriculture, smallscale artisanal elaboration, and retail commerce, where the reproduction of the family unit combines peasant auto-supply, salaried work and multi-activity.

Maize harvest is directed at auto-consumption and when there is an excess it is sold in the local or municipal market. The sub-products of their work are fodder and small maize (molonco), which is ground with rented machinery. It is used to feed the familiar backyard livestock; it is common to sell the excess as fodder at the local or municipal level.

Multi-activity is a peasant family strategy. They occupy their workforce as agricultural day laborers, in construction and in other activities. Depending on their age, males combine family work with their studies (basic to high school). The mothers are in charge of the household chores, they take care of the children and spouse, and they support in agricultural activities, primarily the harvest.

Internal migration is another peasant family strategy. Men and women leave the locality towards the US and the remittances generated by jobs they perform partially alleviate the family needs. Migration is temporary and rarely definitive. It is complemented with agricultural activity, seeking the reproduction of the family unit.

It is recommended not to exclude traditional peasants from subsidies to agriculture, since they are the ones who ensure the countryside agro-biodiversity; also, they conserve the land, foster rootedness, and maintain the genetic diversity of maize.

It is important to reconsider the greenhouse system for its objective to be family auto-supply, economically at the reach of most peasants, without the use of agrichemicals to avoid a negative collateral impact, and to capture rain water, among other things.

The conservation of ecosystems and their biodiversity should be promoted through planting of fruit trees adapted to the zone, on the perimeter of milpas. This activity could provide more products and improve the peasant family income, allowing them to attain a better quality of life (diet) and payment for environmental services.

- End of the English version - 
metodológicas. In: Agroecología y Cambio Climático. LimaPerú. Programa Iberoamericano. Ciencia y Tecnología para el Desarrollo, REDAGRES, SOCLA. pp: 7-20.

Arana, María del S., José de J. Rodríguez, M., y Guillermo D. Carrasco. 2009. La Migración de Jornaleros Agrícolas Tlaxcaltecas a Canadá: un sistema complejo. In: Agricultura Sociedad y Desarrollo. Vol. 6, Número 1. Abril. pp: 61-79.

Aparicio, J., y Meseguer, C. 2010. La economía política de las remesas colectivas: El Programa $3 \times 1$ en los municipios mexicanos. In: Durand y A. Schiaun (Coord). Perspectivas migratorias: un análisis interdisciplinario de la migración internacional. México. Grupo de Estudios de Migración del CIDE (CIDE-MIG). pp: 393-431.

Bartra, Armando. 2010. Campesindios: Aproximaciones a los campesinos de un continente colonizado, Revista Memoria, No 248, Bolivia. La Nación. 13 p.

Buenrostro, Marco. 2009. Las bondades de la milpa. In: Ciencias 92. Revista de Cultura Científica. México, UNAM. Octubre- marzo. pp: 30-32.

Chayanov, Alexander. 1974. La Organización de la Unidad Doméstica Campesina. Buenos Aires, Argentina. Ediciones Nueva Visión.

CEPAL. 1985. Economía campesina y Agricultura Empresarial: Tipología de productores del agro mexicano, México. Editorial Siglo Veintiuno. 339 p.

Damián, Miguel A., Artemio Cruz L., Benito Ramírez V., Omar Romero A. Sergio Moreno, y Luis Reyes. 2012. Maíz, alimentación y productividad: modelo tecnológico para productores de temporal de México. In: Agricultura, Sociedad y Desarrollo. Vol.10. Número 2. Abril- junio. pp: 157-176.
Galeski, Boguslaw. 1997. Sociología del Campesinado. Barcelona. Editorial Península. pp: 133-162.

Geilfus, Frans. 2002. 80 Herramientas para el Desarrollo Participativo: Diagnóstico, Planeación, Monitoreo y Evaluación. México. SAGARPA-IICA/MEXICO-INCA RURAL. 208 p.

Grigg, D. B. 1974. The Agricultural Systems of the World: An Evolutionary Approach, Cambridge, EUA. Cambridge University Press.

Hernández, Roberto, Carlos Fernández C., y Pilar Baptista L. 2005. Metodología de la Investigación. (Cuarta Ed.), México. Mc Graw-Hill. 497 p.

INEGI (Instituto Nacional de Estadística Geografía e Informática). 2000 y 2010. XI y XII, Censos General de Población y Vivienda. Estado de México. México.

Infante, Said, y G. Zarate. 2005. Métodos Estadísticos. (Octava reimpresión) México. Editorial Trillas. pp: 11-16.

Jiménez, Mercedes A. 2010. Alimentación y hongos silvestres en la Sierra Nevada. In: Desarrollo Rural en México (coord Alberti, et al.) México, Plaza y Valdés. pp: 111-122.

Martínez, Tomas. 1987. Campesinado y Política: movimientos o movilizaciones campesinos. In: Glantz, S. (comp). La Heterodoxia Recuperada en torno a Ángel Palerm. México. Fondo de Cultura Económica.

Oswald, Ursula. 2011. Reconceptualizar la seguridad ante los riesgos del cambio climático y la vulnerabilidad social. In: Simone Lucatello y Daniel Rodríguez Velázquez (Coord) Un Panorama desde México, cambio social o crisis ambiental, talleres SIGNE. México, UNAM. pp: 23-41.

Wolf, Eric. 1975. Los campesinos. Ed. Labor. Barcelona. Editorial Labor. 150 p. 